\title{
MOBILE APPLICATION M-WARTA PADA USER READING DENGAN MULTI CLIENT SERVER BERBASIS ANDROID
}

\author{
Agung Ferry Anggara ${ }^{1)}$, M. Ghofar Rohman ${ }^{2)}$, Nurul Fuad ${ }^{3)}$ \\ 1)Program Studi Teknik Informatika Universitas Islam Lamongan \\ 2) Dosen Fakultas Teknik Prodi Teknik Informatika Universitas Islam Lamongan \\ 3) Dosen Fakultas Teknik Prodi Teknik Informatika Universitas Islam Lamongan
}

E-mail : agungf.anggara123@gmail.com ${ }^{1)}$,M.ghofarrohman@unisla.ac.id ${ }^{2)}$, nurulfuad23@ gmail.com ${ }^{3)}$

\begin{abstract}
ABSTRAK
Berita merupakan suatu kebutuhan pokok dalam kehidupan sehari-hari seseorang. Karena manusia hidup pasti membutuhkan sebuah informasi itu tentang pekerjaan, pendidikan, dan sebagainya. Dengan berita seseorang tahu akan sesuatu yang baru. Tanpa berita seseorang dapat dikatakan sebagai katak dalam tempurung. Seseorang dapat mengakses sebuah berita melalui berbagai media, antara lain : media cetak, media elektronik, dan media internet. Kebanyakan orang menginginkan sebuah berita dapat diakses di mana saja dan kapan saja berada. Maka dari itu aplikasi M-Warta dapat menjadikan sebuah berita menjadi portable. Dan bagaimana para penulis berita dapat langsung memberikan sebuah berita pada saat itu juga. Aplikasi ini bersistem client server untuk penulis berita dan pembaca yang dapat memberikan dan menerima informasi yang terbaru. Sasaran utama pengguna layanan berita ini adalah mobile user seperti handphone. Android merupakan salah satu sistem operasi Smartphone yang sedang berkembang saat ini. Android mempunyai banyak keunggulan dibanding sistem operasi lain. Antara lain sistem operasi dapat diubah sesuai dengan keinginan sendiri dan banyak aplikasi komputer yang tersedia untuk Smartphone Android. Oleh karena itu Android saat ini menjadi teknologi yang paling diminati oleh manusia. Aplikasi Android untuk membantu para penulis berita menyampaikan berita dan para pembaca berita untuk menerima berita terbaru.
\end{abstract}

\section{Kata-kata Kunci: Berita, Client Server, Android}

\begin{abstract}
News is a primary thing in the daily life of a person because human life definitely requires an information. That information can be about jobs, education, and so forth. With news, someone knows something new, without news, a person can be said as a frog in a shell. One can access the news through various media, those are; print media, electronic media, and internet media. Most people want news that can be accessed anywhere and anytime. Thus the M-News application can make a news becomes portable news and how news writers can immediately provide a message at that time. The system of this application is client serverfor the news writers and readers that can give and receive the latest information. The main target of this news service users are mobile users such as mobile phones. Android is a smartphone operating system that is being developed at this time. Android has many advantages over other operating systems. Among others, the operating system can be changed in accordance with the users' needs and there are many computer applications available for Android smartphones. Therefore, Android is currently becoming the most enthused technology nowadays. Android application used to help the news writers to deliver the news and the news anchors to receive the latest news.
\end{abstract}

Keywords: News, Client Server, Android

\section{PENDAHULUAN}

Seiring dengan perkembangan zaman, teknologi informasi di dunia ini mengalami kemajuan yang sangat pesat. Salah satunya adalah perkembangan di dunia mobile phone atau handphone. Saat ini manusia tidak dapat terlepas dari smartphone, dengan adanya smart phone akan memudahkan penggunanya untuk mendapatkan berbagai informasi terbaru.
Berita merupakan suatu kebutuhan pokok dalam kehidupan sehari-hari seseorang. Karena manusia hidup pasti membutuhkan sebuah informasi itu tentang pekerjaan, pendidikan, dan sebagainya. Dengan berita seseorang tahu akan sesuatu yang baru.

Tanpa berita seseorang dapat dikatakan sebagai katak dalam tempurung. Seseorang dapat mengakses sebuah berita melalui 
berbagai media, antara lain : media cetak, media elektronik, dan media internet. Kebanyakan orang menginginkan sebuah berita dapat diakses di mana saja dan kapan saja berada. Maka dari itu timbul sebuah pemikiran bagaimana menjadikan berita itu menjadi portable. Dan bagaimana para penulis berita dapat langsung memberikan sebuah berita pada saat itu juga.

Oleh karena itu, akan dibangun sebuah aplikasi bersistem client server untuk para penulis berita dan para pembaca yang dapat memberikan dan menerima informasi yang terbaru. Sasaran utama pengguna layanan berita ini adalah mobile user seperti handphone. Pada era komputerisasi saat ini, Smartphone adalah barang yang sedang tren. Banyak masyarakat yang menggunakan Smartphone untuk kebutuhan sehari hari karena memiliki beragam fitur dari Smartphone tersebut. Diantara banyak Smartphone yang beredar sekarang ada beberapa sistem operasi yang mendukung Smartphone, yaitu Windows Mobile, Blackberry, Symbian, Iphone, Android dan lain-lain. Android merupakan salah satu sistem operasi Smartphone yang sedang berkembang saat ini. Android mempunyai banyak keunggulan dibanding sistem operasi lain. Antara lain sistem operasi dapat diubah sesuai dengan keinginan sendiri dan banyak aplikasi komputer yang tersedia untuk Smartphone Android. Oleh karena itu Android saat ini menjadi teknologi yang paling diminati oleh manusia.

\section{TINJAUAN PUSTAKA Berita}

Dalam Kamus Besar Bahasa Indonesia (KBBI), berita adalah cerita atau keterangan mengenai kejadian atau peristiwa yang hangat. Berita disajikan lewat bentuk cetak, siaran, Internet, atau dari mulut ke mulut kepada orang ketiga atau orang banyak. Laporan berita merupakan tugas profesi wartawan, saat berita dilaporkan oleh wartawan laporan tersebut menjadi fakta atau ide terkini yang dipilih secara sengaja oleh redaksi pemberitaan atau media untuk disiarkan dengan anggapan bahwa berita yang terpilih dapat menarik khalayak banyak karena mengandung unsur-unsur berita.

Stasiun televisi biasanya memiliki acara berita atau menayangkan berita sepanjang waktu. Kebutuhan akan berita ada dalam masyarakat, baik yang melek huruf maupun yang buta huruf.

\section{Pentingnya 5W+1H}

Menulis berita bukan sekadar mencurahkan isi hati. Sebuah berita harus dapat dipertanggungjawabkan kebenarannya, aktual, dan informatif. Tidak seperti menulis karangan yang mendayu-dayu. Kualitas berita tentu harus memenuhi kriteria umum penulisan, yaitu $5 \mathrm{~W}+1 \mathrm{H}$ yang sudah menjadi 'sego jangan' (di luar kepala) buat seorang jurnalis. Selain syarat tersebut, sebenarya ada juga syarat yang juga wajib dimengerti oleh seorang jurnalis, yaitu persyaratan bentuk. Dalam jurnalistik syarat bentuk ini lebih sering dikenal dengan sebutan 'Piramida Terbalik'. Kenapa disebut Piramida Terbalik, karena bentuknya memang mirip dengan piramida mesir namun posisinya terbalik.

Mengapa kedua hal ini disebut sebagai dasar menulis bagi wartawan. Kedua teknik ini juga bisa, dan memang efektif, dipakai oleh penulis non-wartawan, termasuk bloger.

$5 \mathrm{~W}=1 \mathrm{H}$ adalah singkatan dari "what, who, when, where, why, how," yang dalam bahasa Indonesia menjadi "apa, siapa, kapan, di mana, mengapa, bagaimana." Semua unsur inilah yang harus terkandung dalam sebuah artikel biasa atau berita biasa. Artikel berbentuk berita memiliki struktur unik: Inti informasi ditulis pada alinea awal (disebut sebagai "lead" atau "teras berita"; biasanya satu hingga dua paragraf), data-data penting menyusul pada alinea-alinea selanjutnya, lalu penjelasan tambahan, dan diakhiri dengan informasi lain yang bukan bersifat informasi utama. Inilah yang disebut sebagai piramida terbalik.

Piramida Terbalik adalah sebuah struktur penulisan atau bentuk penyajian sebuah tulisan yang umum dilakukan seorang wartawan. Kenapa harus menggunakan metode Piramida Terbalik, tentu maksudnya adalah agar pembacara dapat segera mengetahui inti dari berita yang ingin diketahuinya. Apalagi disaat seperti sekarang yang serba cepat. Berita online misalkan, sebaiknya dalam menyampaikan berita langsung ke pokok beritanya. Informasi- informasi penting (inti) disajikan di awal paragraf, selanjutnya informasi pendukung mengikuti paragraf berikutnya. 
Bagi pembaca sebuah artikel, piramida terbalik memudahkannya menangkap inti cerita, sebab informasi yang paling pokok langsung dibeberkan sejak alinea-alinea awal. Bagi wartawan maupun redaktur, akan memudahkan dalam penulisan dan editing berita, karena mereka lebih fokus pada pokok pikiran berita yang mereka tuliskan. Sedangkan redaktur pun akan sangat mudah dalam menyunting ataupun memotong berita, tinggal menghapus paragrafparagraf akhir yang dianggap tidak terlalu penting. Sedangkan bagi media dengan penulisan Piramida Terbalik ini, akan menghemat space halaman.

\section{Android}

Android adalah sistem informasi untuk telepon seluler (mobile) seperti pada smartphone dan komputer tablet. Sistem operasi android berbasis linux yang bersifat terbuka (open source) bagi pengembang untuk menciptakan aplikasi maupun mengembangkan android dengan tools yang disediakan yaitu android SDK (Software Development Kit) dan API (Application Programming Interface) dengan menggunakan bahasa pemrograman java. Dikembangkan oleh Google Inc, HTC, Intel, Motorola, Qualcom, T-Mobile, dan Nvidia yang tergabung dalam Open Handset Alliance (OHA), dengan tujuan mendukung sebuah standar terbuka pada perangkat seluler. Kode-kode yang dirilis oleh google untuk android berada dibawah license apache, sebuah license perangkat lunak dan standar terbuka bagi perangkat seluler.

\section{Versi Android}

Beberapa uraian versi android seperti dibawah ini :

a. Android versi 1.1

b. Android versi 1.5 (Cupcake)

c. Android versi 1.6 (Donut)

d. Android versi 2.0/2.1 (Éclair)

e. Android versi 2.2 (Froyo: Frozen Yoghurt)

f. Android versi 2.3 (Gingerbread)

g. Android versi 3.0 (Honeycomb)

h. Android versi 4.0 (Ice Cream Sandwich)

i. Android versi 4.1 (Jelly Bean)

j. Android versi 4.4 (KitKat)

k. Android versi 5.0 (Lollipop)

1. Android versi 6.0 (Marshmallow)

\section{Android Studio}

Android Studio adalah sebuah IDE untuk Android Development yang diperkenalkan google pada acara Google I/O 2013.Android Studio merupakan pengembangkan dari Eclipse IDE, dan dibuat berdasarkan IDE Java populer, yaitu Intel IDEA. Android Studio merupakan IDE resmi untuk pengembangan aplikasi Android.

Sebagai pengembangan dari Eclipse, Android Studio mempunyai banyak fitur-fitur baru dibandingkan dengan Eclipse IDE. Berbeda dengan Eclipse yang menggunakan Ant, Android Studio menggunakan Gradle sebagai build environment. Fitur-fitur lainnya adalah sebagai berikut :

- Menggunakan Gradle-based build system yang fleksibel.

- Bisa mem-build multiple APK .

- Template support untuk Google Services dan berbagai macam tipe perangkat.

- Layout editor yang lebih bagus.

- Built-in support untuk Google Cloud Platform, sehingga mudah untuk integrasi dengan Google Cloud Messaging dan App Engine.

- Import library langsung dari Maven repository.

- dan masih banyak lagi lainnya.

\section{Web Server}

Server web atau yang dalam bahasa inggris disebut web server adalah merupakan perangkat lunak (software) dalam server yang berfungsi untuk menerima permintaan (request) berupa halaman web melalui protokol HTTP dan atau HTTPS dari client yang lebih dikenal dengan nama browser, kemudian mengirimkan kembali (respon) hasil permintaan tersebut ke dalam bentuk halaman-halaman web yang pada umumnya berbentuk dokumen HTML.

Dari pengertian diatas, dapat disimpulkan bahwa web server merupakan pelayan (pemberi layanan) bagi web client (browser) seperti Mozilla, Chrome, Internet Explorer, Opera, Safari dan lain sebagainya, supaya browser dapat menampilkan halaman atau data yang anda minta.

\section{PHP}

PHP adalah bahasa pemrograman script yang paling banyak dipakai saat ini. PHP banyak dipakai untuk memrogram situs web 
dinamis, walaupun tidak tertutup kemungkinan digunakan untuk pemakaian lain. Contoh terkenal dari aplikasi PHP adalah forum (phpBB) dan MediaWiki (software di belakang Wikipedia). PHP juga dapat dilihat sebagai pilihan lain dari ASP.NET/C\#/VB.NET Microsoft, ColdFusion Macromedia, JSP/Java Sun Microsystems, dan CGI/Perl. Contoh aplikasi lain yang lebih kompleks berupa CMS yang dibangun menggunakan PHP adalah Mambo, Joomla!, Postnuke, Xaraya, dan lainlain.

Pada awalnya PHP merupakan kependekan dari Personal Home Page (Situs Personal). PHP pertama kali dibuat oleh Rasmus Lerdorf pada tahun 1995. Pada waktu itu PHP masih bernama FI (Form Interpreted), yang wujudnya berupa sekumpulan script yang digunakan untuk mengolah data form dari web.

Selanjutnya Rasmus merilis kode sumber tersebut untuk umum dan menamakannya PHP/FI. Dengan perilisan kode sumber ini menjadi open source, maka banyak programmer yang tertarik untuk ikut mengembangkan PHP.

\section{MySql}

MySQL adalah sebuah perangkat lunak system manajemen basis data SQL (DBMS) yang multithread, dan multi-user. MySQL adalah implementasi dari system manajemen basisdata relasional (RDBMS). MySQL dibuah oleh TcX dan telah dipercaya mengelola system dengan 40 buah database berisi 10.000 tabel dan 500 di antaranya memiliki 7 juta baris.

MySQL AB merupakan perusahaan komersial Swedia yang mensponsori dan yang memiliki MySQL. Pendiri MySQL AB adalah dua orang Swedia yang bernama David Axmark, Allan Larsson dan satu orang Finlandia bernama Michael "Monty". Setiap pengguna MySQL dapat menggunakannya secara bebas yang didistribusikan gratis dibawah lisensi GPL(General Public License) namun tidak boleh menjadikan produk turunan yang bersifat komersial.

\section{PEMBAHASAN}

\section{Tahap Desain (Perancangan Sistem)}

Alur sistem adalah struktur progam yang di jelaskan langkah-langkah dengan menggunakan desain proses dan desain UML. Mulai dari Use case diagram, Activity diagram, dan Sequence diagram serta alur basis data pada server yaitu dengan CDM dan PDM. Menggambarkan jalannya progam sampai dengan hubungan dari aplikasi penulis berita sampai ke pembaca berita, tampilan program serta apa yang akan dipilih oleh user.

\section{Use Case Diagram}

Use case diagram adalah gambaran graphical dari beberapa atau semua actor, use-case dan iteraksi diantara komponenkomponen tersebut yang memperkanalkan suatu sistem yang akan dibangun. Use-case diagram menjelaskan manfaat suatu sistem jika dilihat menurut pandangan orang yang berada di luar sistem.

1. Use Case Diagram Penulis Berita

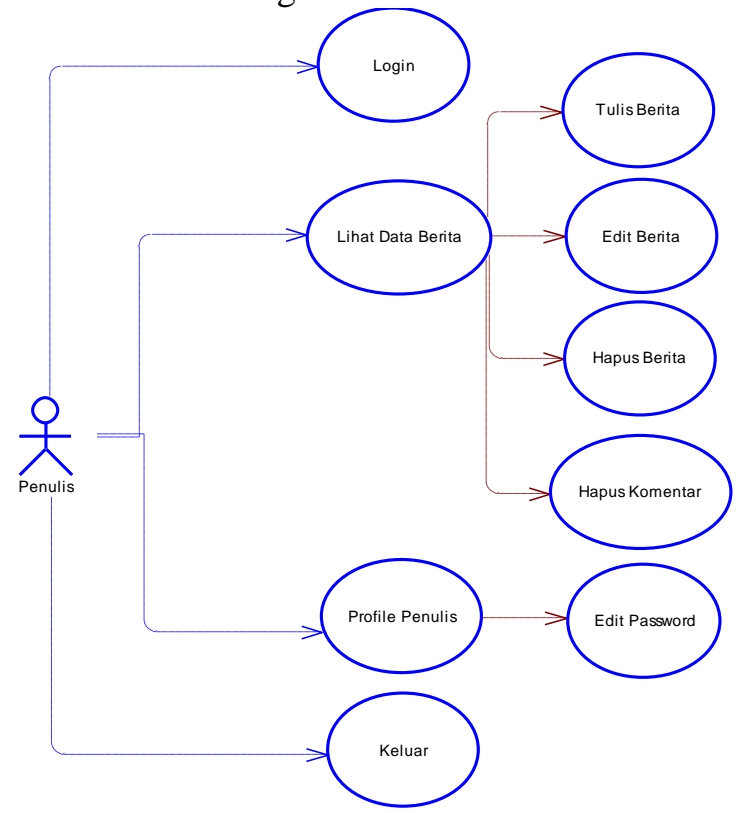

Gambar 1 Use Case Diagram Penulis Berita

2. Use case Diagram Pembaca Berita

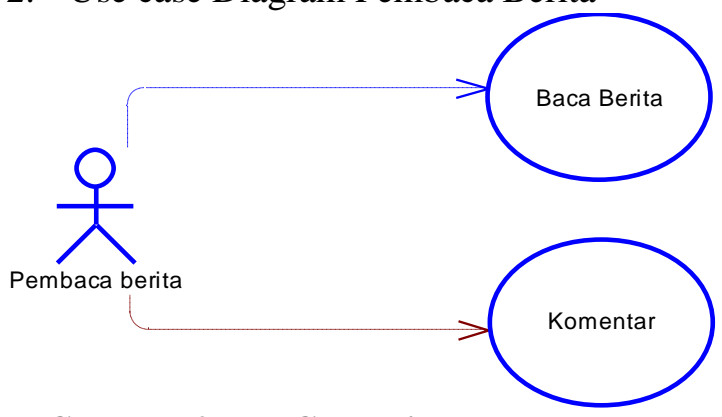

Gambar 2 Use Case Diagram Pembaca Berita 
3. Use Case Diagram Server

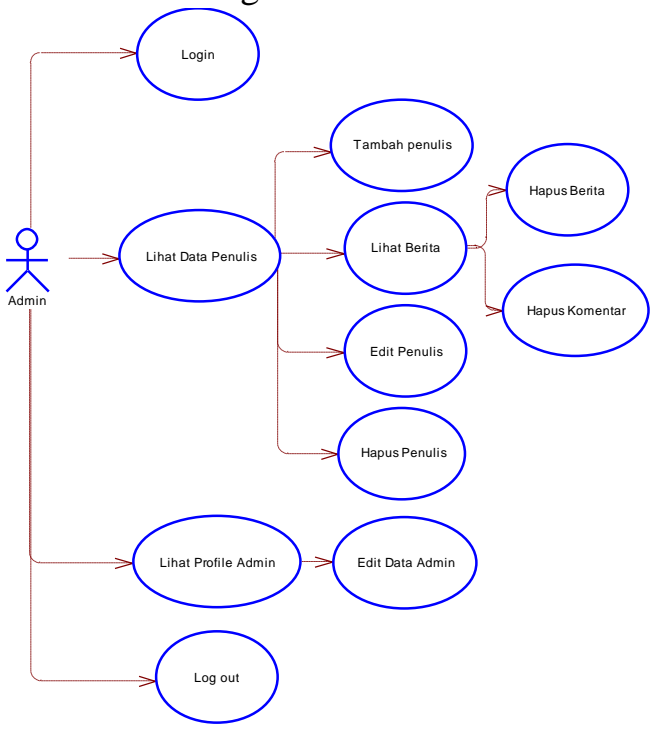

Gambar 3 Use Case Diagram Server

\section{Activity Diagram}

Activity diagram juga dapat menggambarkan proses parallel yang mungkin terjadi pada beberapa eksekusi. Representasi grafis dari alur kerja di dalam menu. Definisi dan keutamaan dari aktivitas mulai sampai ke tahapan berhenti.

1. Activity Diagram Pembaca Berita

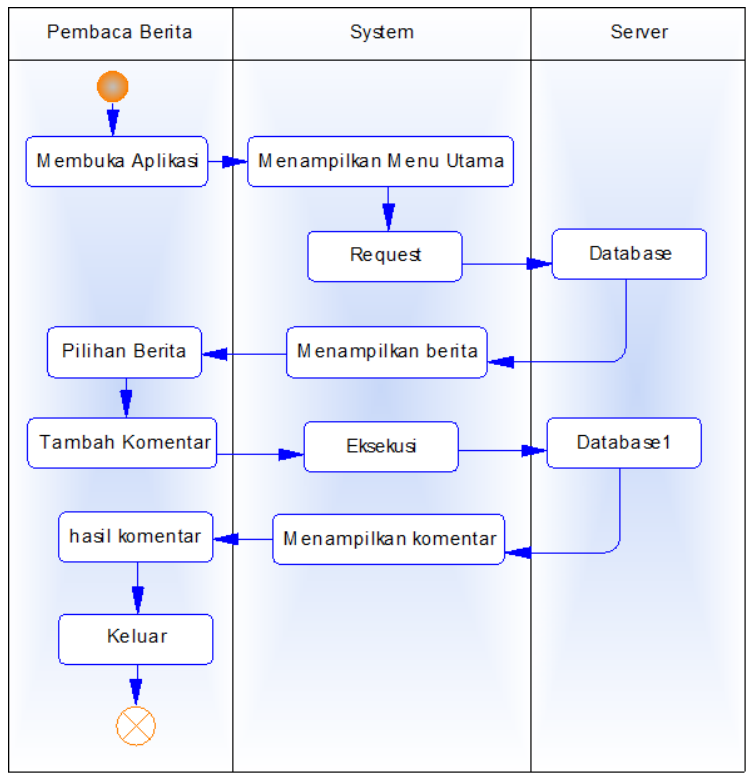

Gambar 4 Activity Diagram Pembaca Berita
2. Activity Diagram Penulis Berita

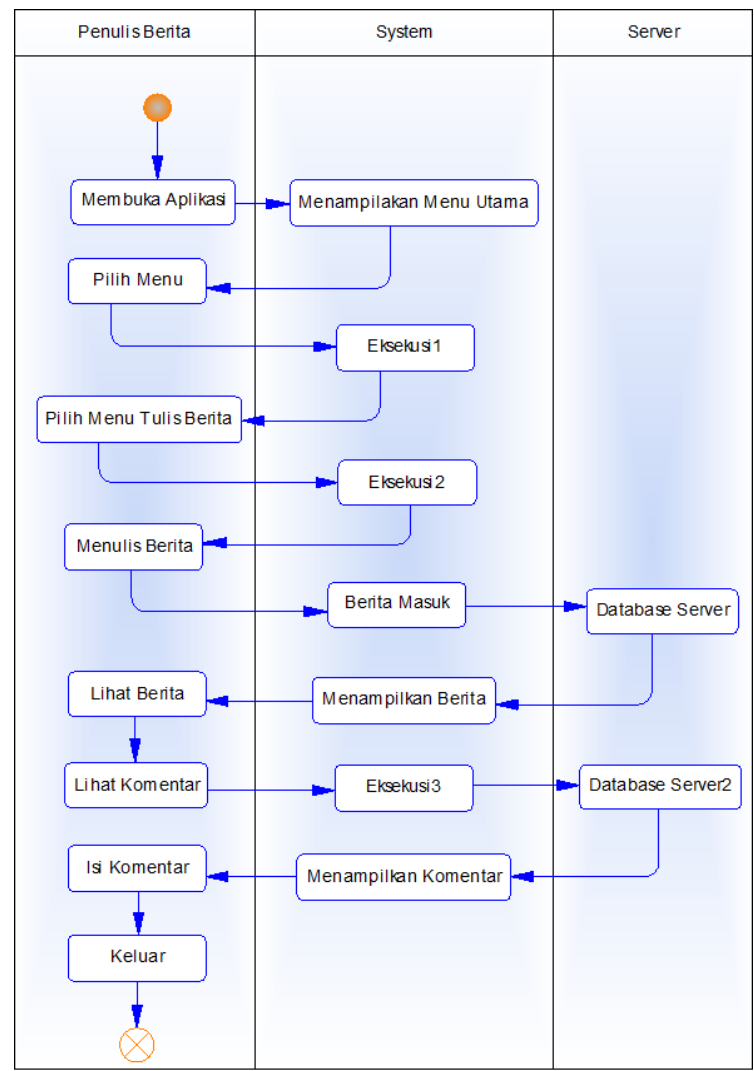

\section{Gambar 5 Activity Diagram Penulis Berita}

3. Activity Diagram Server

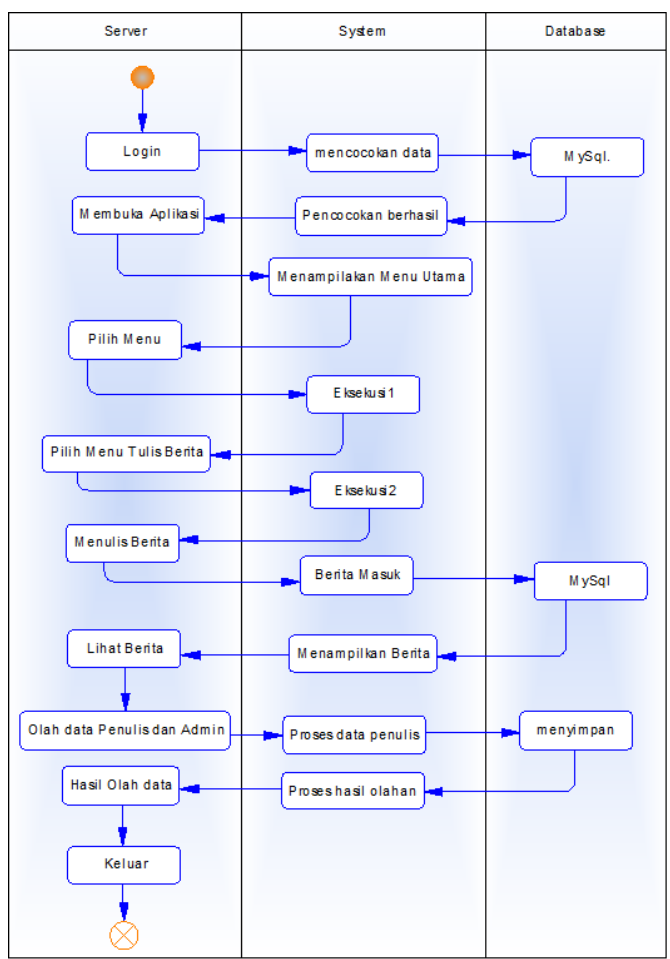

Gambar 6 Activity Diagram Server 


\section{Squence Diagram}

Sebuah squance diagram, secara khusus menjabarkan behavior sebuah skenario tunggal. Diagram tersebut menunjukan sejumlah objek contoh dan pesan-pesan yang melewati objekobjek ini di dalam use case.

1. Sequence Diagram Penulis Berita

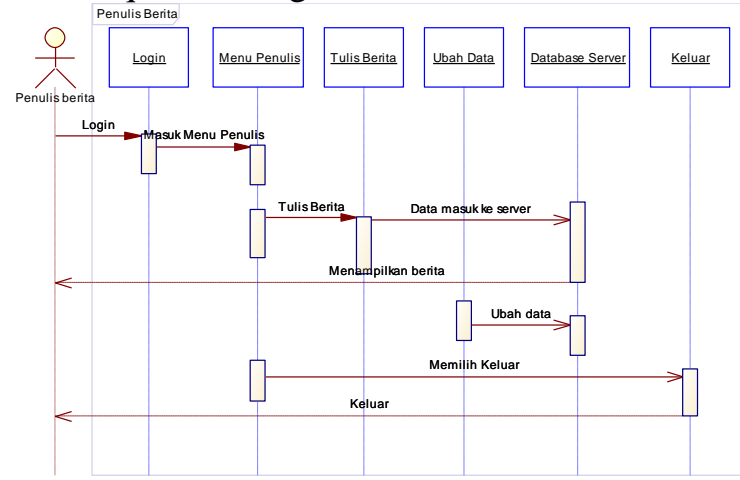

Gambar 7 Sequence Diagram Penulis Berita

2. Sequence Diagram Pembaca Berita

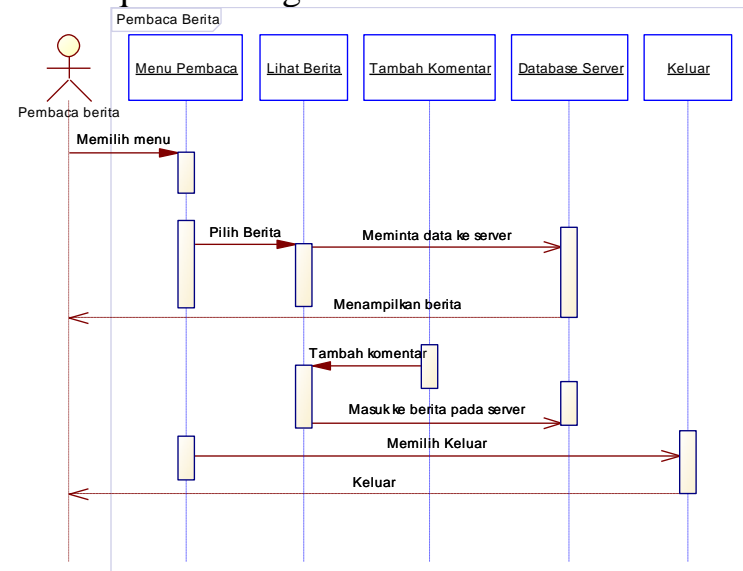

Gambar 8 Sequence Diagram Pembaca Berita

3. Sequence Diagram Server

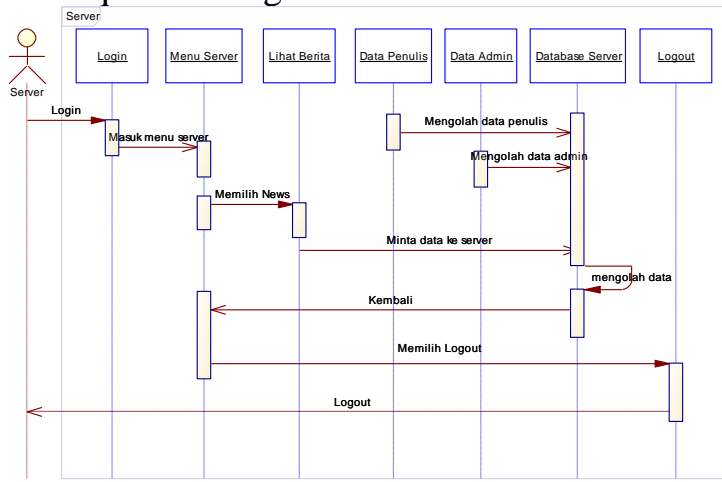

Gambar 9 Sequence Diagram Server

\section{Perancangan Database \\ Conceptual Data Model (CDM)}

Conceptual Data Model atau biasa disebut CDM memodelkan struktur logis dari keseluruhan aplikasi data, tidak tergantung pada software atau pertimbangan model struktur data.

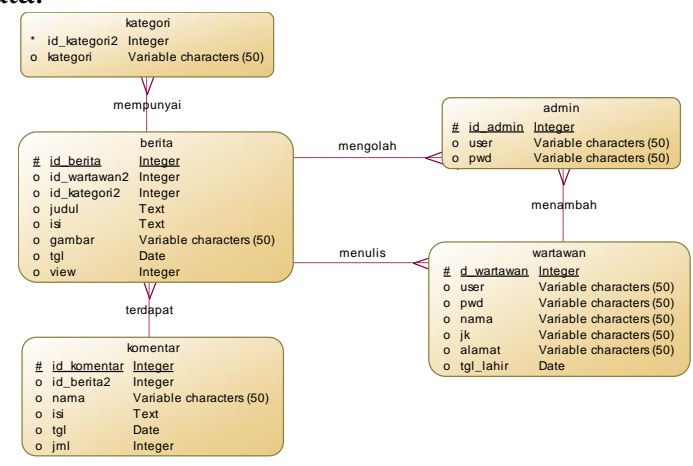

\section{Gambar 10 Conceptual Data Model}

\section{Physical Data Model}

Physical

Data

Model

merupakan gambaran secara detail basis data dalam bentuk fisik. Penggambaran rancangan PDM memperlihatkan struktur penyimpanan data yang benar pada basis data yang digunakan sesungguhnya.

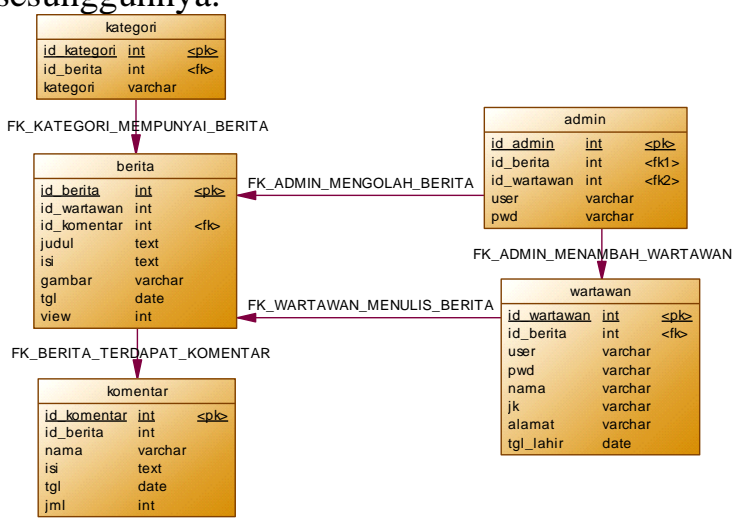

Gambar 11 Physical Data Model

\section{Perancangan Interface}

1. Interface Penulis Berita

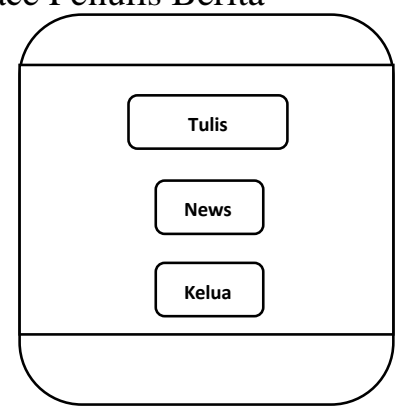

Gambar 12 Interface Penulis Berita 
2. Interface Pembaca Berita

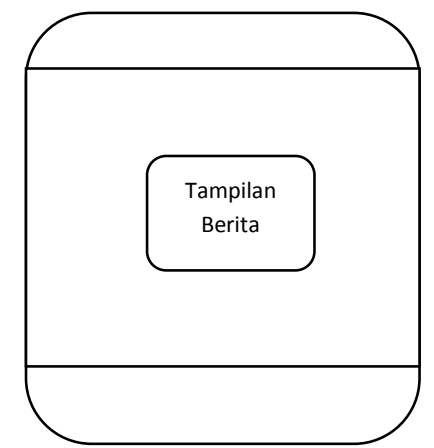

Gambar 13 Interface Pembaca Berita

3. Interface Server

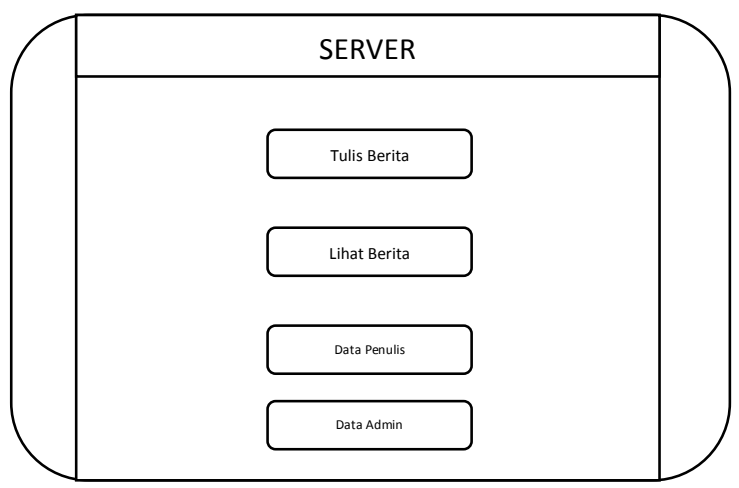

Gambar 14 Interface Server

\section{Manual Program}

Manual program berisi tampilan dan cara penggunaan masing masing form dari aplikasi M-Warta ini. Dengan begitu, user dapat menjalankan aplikasi ini dengan mudah dan tanpa ada kesulitan yang berarti.

\section{Aplikasi Penulis Berita}

Form menu utama pada aplikasi penulis berita ini merupakan form pusat dari segala fitur yang ada pada aplikasi penulis berita. Pengguna diharuskan untuk login.

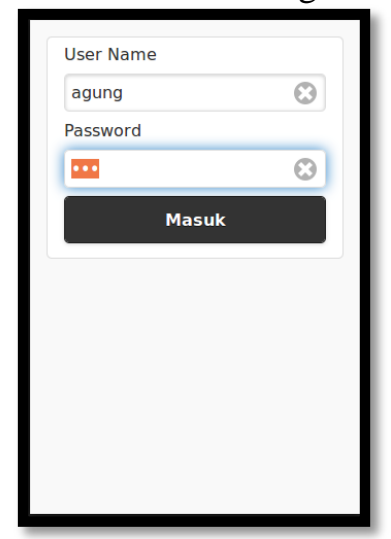

Gambar 15 Form Menu Login Penulis Berita

\section{Aplikasi Pembaca Berita}

Pada form menu utama untuk pembaca ini, pengguna akan langsung ditampilkan semua berita yang ada pada server. Pengguna langsung dapat memilih berita yang tersedia pada aplikasi tersebut. Pengguna dapat memilih mulai berita terbaru sampai yang paling banyak dibuka oleh pembaca lain.

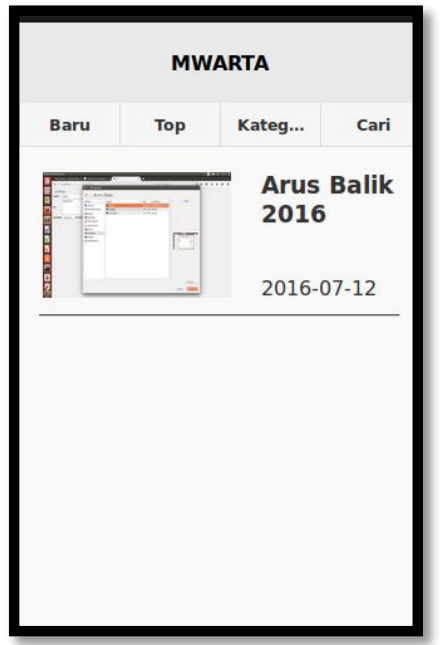

\section{Gambar 16 Tampilan Lihat Berita}

\section{Aplikasi Server}

Tampilan login adalah tampilan pertama yang tampil ketika admin membuka aplikasi server dengan cara menginputkan username dan password. Username dan password yang diinputkan sudah terdapat pada basis data, dan hanya admin yang dapat mengubah username dan passwordnya sendiri. Setelah Login maka akan menuju ke halaman Home. Halaman ini berisi halaman awal pada server.

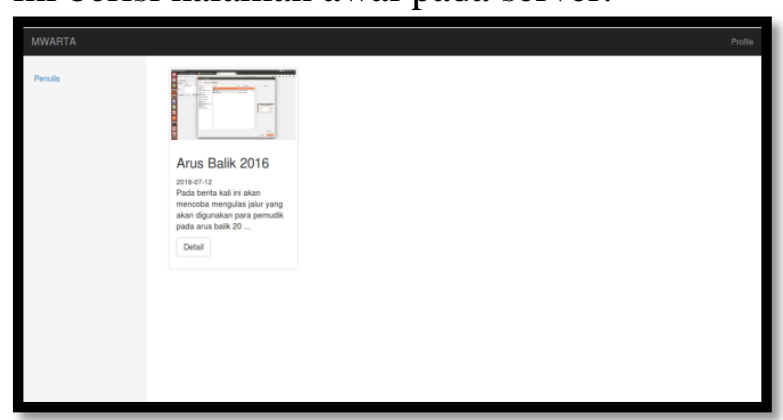

\section{Gambar 17 Tampilan Server}

\section{KESIMPULAN}

Dari penjelasan dan uraian pada bab-bab sebelumnya, serta dari hasil pengamatan setelah 
perancangan program maka dapat disimpulkan bahwa :

Aplikasi ini dibuat untuk sistem operasi android dengan tujuan agar lebih memudahkan penulis berita untuk menyampaikan berita, dan pembaca berita untuk menerima berita.

Dengan adanya aplikasi ini, penyampaian berita oleh penulis berita dapat lebih efisien karena berita dapat lebih cepat disampaikan kepada pembaca berita saat itu juga.

\section{PUSTAKA}

Anonim. 2015. Pengertian MySql, http://www.kompinterku.com/ Diakses 02 Juni 2016.

Fatimah, Wina Noviani. 2011. Rancang Bangun Aplikasi Pemesanan Makanan dan Minuman Pada Ketty Berbasis Client Server dengan Platform Android. Diakses 29 Mei 2016. [https: // wi01. files. Wordpress. com/ pengenalan-eclipse.pdf]. 